\title{
A hydrotalcite-based catalyst system for the single-stage liquid-phase synthesis of MIBK
}

\author{
Ferry Winter, Mariska Wolters, A. Jos van Dillen, Krijn P. de Jong* \\ Inorganic Chemistry and Catalysis, Department of Chemistry, Utrecht University, \\ P.O. Box 80 083, 3508 TB Utrecht, The Netherlands
}

Received 10 February 2006; received in revised form 23 March 2006; accepted 29 March 2006

Available online 5 May 2006

\begin{abstract}
A comparative study was performed between Pd supported on activated hydrotalcites bi-functional catalysts and physical mixtures of activated hydrotalcites with Pd supported on carbon nanofibers for the single-stage liquid-phase synthesis of methyl isobutyl ketone from acetone and $\mathrm{H}_{2}$. Since it was found earlier that the dehydration reaction of diacetone alcohol over activated hydrotalcites is the rate-determining step in this process, $\mathrm{Mg}-\mathrm{Al}$ hydrotalcites were investigated in the condensation of acetone to diacetone alcohol and its dehydration to mesityl oxide to enhance the activity. A correlation between the number of active base sites, as determined by volumetric $\mathrm{CO}_{2}$ adsorption measurements at low pressures, and the activity in the dehydration reaction could be derived. A dependency on the Pd-loading (0-1 wt \%) of Pd supported on activated hydrotalcites catalysts was found in the single-stage synthesis of methyl isobutyl ketone, whereas no such an effect was found when using physical mixtures of activated hydrotalcites with Pd on carbon nanofibers. Results from TEM, $\mathrm{CO}_{2}$ chemisorption and $\mathrm{N}_{2}$ physisorption as well as catalytic experiments in the hydrogenation of mesityl oxide and of cyclohexene indicate that this dependency is largely accounted for by entrapment of Pd particles in the agglomerates of the irregular stacks of hydrotalcite platelets, making these sites inaccessible for the reactants.
\end{abstract}

(C) 2006 Elsevier B.V. All rights reserved.

Keywords: Hydrotalcite; Layered double hydroxide; LDH; Solid base catalyst; Palladium; Methyl isobutyl ketone; MIBK; Hydrogenation; Bi-functional catalyst

\section{Introduction}

Industrially important chemicals like methyl isobutyl ketone (MIBK) and 2-ethylhexanal are usually produced in a three-step process, wherein the three reactions steps are executed separately. The first step is a base-catalyzed aldol condensation, followed by a dehydration reaction which can be catalyzed under acidic or under basic conditions [1]. The last step is the selective hydrogenation of the, $\alpha, \beta$-unsaturated aldehyde or ketone. The three-step process is disadvantageous, because the yield of the first two steps is limited by the thermodynamic equilibria while only the third step, the hydrogenation, is thermodynamically favored towards the endproduct [2-4]. Furthermore, the large waste streams from the use of homogeneous catalysts have to be reduced significantly. To deal with the thermodynamic constraints and the more stringent environmental legislation, several catalytic systems

\footnotetext{
* Corresponding author. Tel.: +31302536762; fax: +31 302511027. E-mail address: k.p.dejong@chem.uu.nl (K.P. de Jong).
}

have been investigated for the single-stage process wherein $n$-butyraldehyde and $\mathrm{H}_{2}$ into 2-ethylhexanal or acetone and $\mathrm{H}_{2}$ into MIBK are directly converted. Examples of these catalytic systems are $\mathrm{Pd}$ on ion-exchange resin [5], Pd or Pt on ZSM-5 [6-8], $\mathrm{Pd}$ on zeolite $\mathrm{X}$ [9,10], $\mathrm{Pd}$ on $\mathrm{Na} / \mathrm{SiO}_{2}$ [11], $\mathrm{Pd} / \mathrm{Nb}_{2} \mathrm{O}_{5} /$ $\mathrm{SiO}_{2}[12,13], \mathrm{Ni} / \gamma-\mathrm{Al}_{2} \mathrm{O}_{3}$ [14] and $\mathrm{Ni}$ or $\mathrm{Pd}$ on $\mathrm{Mg}(\mathrm{Al}) \mathrm{O}$ [1521]. Although these single-stage processes seem promising, still high reaction temperatures and pressures are required and side-reactions occur that lower the selectivity of the process and cause catalyst deactivation $[17,22,23]$. Although the use of catalytic distillation [24] might overcome these problems, a process operating at low temperatures appears to be more suitable.

Recently, we reported a preliminary study of a hydrotalcitebased catalyst system consisting of a physical mixture of activated $\mathrm{Mg}-\mathrm{Al}$ hydrotalcites (HT) and palladium supported on carbon nanofibers ( $\mathrm{Pd} / \mathrm{CNF}$ ) for the single-stage synthesis of MIBK [25]. This catalyst system converts acetone and $\mathrm{H}_{2}$ into MIBK in the liquid-phase under mild conditions $(331 \mathrm{~K}$ and 1.2 bar $\mathrm{H}_{2}$ ) with high selectivity, although more research is required to further improve the activity. As the condensation of 
acetone to diacetone alcohol (DAA) over HT proceeded very fast and the second step, the dehydration of DAA to mesityl oxide (MO) over HT, was found to be rate limiting in the production of MIBK, the MIBK production rate may be improved by enhancing the rate of the dehydration reaction. However, in our previous work we showed that already at low MO concentrations severe deactivation of the hydrogenation catalyst occurred due to oligomerization of MO. The balance between the rate of the dehydration reaction and of the hydrogenation to MIBK is crucial in maintaining very low MO concentrations to suppress deactivation of the hydrogenation functionality. With a physical mixture of activated HT and Pd/ CNF this balance may be shifted with the composition of the mixture. An alternative could be the use of a bi-functional catalyst, in which the distance between the basic sites and hydrogenation sites is minimized. The main advantage of such a catalyst system might be that MO does not necessarily have to desorb from the catalyst, but can be hydrogenated directly into MIBK. Therefore, it is beneficial to perform a comparison between hydrotalcite-based bi-functional catalysts and physical mixtures.

The deposition of highly dispersed $\mathrm{Pd}$ supported on hydrotalcites has been executed using various synthesis methods, such as co-precipitation [18], deposition-precipitation [26], impregnation [27-29] or by use of Pd clusters in a polymer [30]. However, the main focus of these studies was on the hydrogenation reaction and no attention has been given on the basic function. Recently, Tichit et al. [29] reported on Pd supported on a $\mathrm{Mg} / \mathrm{Al}$ mixed oxide as an efficient catalyst for the synthesis of 2-methyl-3-phenyl-propanal from benzaldehyde and 2-propanal, wherein basic sites as well as hydrogenation sites are required. An interesting finding was that by adding water to the reaction mixture the activity increased significantly, because reconstruction of the mixed oxide to hydrotalcites occurred. By reconstruction to hydrotalcite strong Brønsted-base sites $\left(\mathrm{OH}^{-}\right)$were incorporated in the structure, which were responsible for the significant increase in catalytic activity. Therefore, this reconstructed material is of interest to investigate in the single-stage synthesis of MIBK from acetone and $\mathrm{H}_{2}$.

In this paper we report on a comprehensive study on hydrotalcite-based catalysts for the single-stage liquid-phase synthesis of MIBK from acetone and $\mathrm{H}_{2}$ under mild conditions. The dehydration of DAA to MO over activated Mg-Al HT was studied separately to enhance the rate-determining step. To this end HT with different platelet sizes were investigated to derive the relation between the number of active sites and the catalytic performance for this reaction. Furthermore, since water is a side-product in the dehydration reaction, investigation on the influence of water is performed. A comparative study was made between Pd supported on activated hydrotalcites bi-functional catalysts and physical mixtures of activated hydrotalcites with $\mathrm{Pd}$ on carbon nanofibers in the single-stage liquid-phase

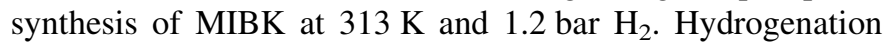
experiments were performed separately to obtain more detailed information about the catalytic properties of the hydrogenation function of the catalysts.

\section{Experimental}

\subsection{Preparation of the hydrotalcite materials}

$\mathrm{HT}$ with an $\mathrm{Mg} / \mathrm{Al}$ ratio of 2 was prepared via coprecipitation [25,31]. To an aqueous solution $(70 \mathrm{ml})$ containing $0.35 \mathrm{~mol} \mathrm{NaOH}$ (Merck) and $0.09 \mathrm{~mol} \mathrm{Na}_{2} \mathrm{CO}_{3}$ (Acros) an aqueous solution $(45 \mathrm{ml})$ of $0.1 \mathrm{~mol} \mathrm{Mg}\left(\mathrm{NO}_{3}\right)_{2} \cdot 6 \mathrm{H}_{2} \mathrm{O}$ (Acros) and $0.05 \mathrm{~mol} \mathrm{Al}\left(\mathrm{NO}_{3}\right)_{3} \cdot 9 \mathrm{H}_{2} \mathrm{O}$ (Merck) was added. The resulting white suspension was heated at $333 \mathrm{~K}$ for $24 \mathrm{~h}$ under vigorous stirring, after which the precipitate was filtered and washed extensively. The sample, further designated as $\mathrm{HT}_{\mathrm{as}}$, was dried for $24 \mathrm{~h}$ at $393 \mathrm{~K}$. For the HT samples prepared at temperatures of 373,423 and $473 \mathrm{~K}$ an autoclave was used. These samples are further indicated with their respective synthesis temperature.

To activate $\mathrm{HT}_{\mathrm{as}}[32,33]$ it was heated in a nitrogen flow to $723 \mathrm{~K}\left(10 \mathrm{~K} \mathrm{~min}^{-1}\right)$ for $8 \mathrm{~h}$ and allowed to cool down to room temperature $\left(\mathrm{HT}_{\text {heat }}\right)$. $\mathrm{HT}_{\text {heat }}$ was rehydrated by suspending it in decarbonated water under $\mathrm{N}_{2}$ atmosphere for $1 \mathrm{~h}$. Next, the sample was filtered under $\mathrm{N}_{2}$ atmosphere and dried in $\mathrm{N}_{2}$ flow at $293 \mathrm{~K}$. The sample is further denoted as $\mathrm{HT}_{\text {re }}$.

\subsection{Deposition of palladium on activated hydrotalcites}

Pd was deposited via a method adapted from literature [2729]. Typically $1.5 \mathrm{~g}$ of $\mathrm{HT}_{\text {heat }}$ was added to a toluene solution $(20 \mathrm{ml})$ containing appropriate amounts of $\mathrm{Pd}(\text { acac })_{2}$ (Acros) (intended loading in the range of $0-1 \mathrm{wt} \%$ ). The solvent was evaporated under continuously stirring the suspension while applying a dynamic vacuum. After drying in $\mathrm{N}_{2}$ flow at $393 \mathrm{~K}$ for $16 \mathrm{~h}$, the catalyst precursor was heated in an Ar flow at $723 \mathrm{~K}$ for $0.5 \mathrm{~h}$. Subsequently, the temperature was lowered to the reduction temperature $(473 \mathrm{~K})$ and the sample was kept at this temperature for $2 \mathrm{~h}$ in a $20 \% \mathrm{H}_{2}$ in Ar flow, followed by rehydration at room temperature by use of a water-saturated nitrogen flow for $72 \mathrm{~h}$ (samples are further denoted as $\mathrm{Pd} / \mathrm{HT}_{\mathrm{re}}$ ).

\subsection{Preparation of $\mathrm{Pd} / \mathrm{CNF}$ and $\mathrm{Pd} / \mathrm{SiO}_{2}$}

Pd was deposited on carbon nanofibers ( $0.9 \mathrm{wt} \% \mathrm{Pd})$ by ion adsorption as described elsewhere [25,34]. Carbon nanofibers (CNF) were grown out of synthesis gas $\left(\mathrm{CO} / \mathrm{H}_{2}\right)$ using a commercial $57 \mathrm{wt} \% \mathrm{Ni} / \mathrm{SiO}_{2}$ catalyst (Engelhard Ni5270P) at a growth temperature of $773 \mathrm{~K}$. Removal of the growth catalyst and oxidation of CNF was performed by treatment in $\mathrm{KOH}$ and subsequently in concentrated $\mathrm{HNO}_{3}$, followed by thorough washing. Next, Pd was deposited by ion adsorption using $\mathrm{Pd}\left(\mathrm{NH}_{3}\right)_{4}\left(\mathrm{NO}_{3}\right)_{2}$. The catalyst precursor was reduced at $523 \mathrm{~K}$ in $\mathrm{H}_{2}$ flow (further denoted as $\mathrm{Pd} / \mathrm{CNF}$ ). A $3 \mathrm{wt} \% \mathrm{Pd}$ on $\mathrm{SiO}_{2}$ catalyst obtained from Engelhard (Q500-189, unreduced sample) was reduced in $\mathrm{H}_{2}$ flow at $523 \mathrm{~K}$ for $2 \mathrm{~h}$.

\subsection{Catalyst characterization}

Powder X-ray diffraction patterns were measured using an Enraf-Nonius CPS 120 powder diffraction apparatus with Co 
$\mathrm{K} \alpha$ radiation $(\lambda=1.789 \AA)$. Volumetric $\mathrm{CO}_{2}$ adsorption measurements in the range of $0-50 \mathrm{mbar}$ were performed at $273 \mathrm{~K}$ with a Micromeritics ASAP 2010C apparatus after drying the samples at $393 \mathrm{~K}$ in vacuum for at least $20 \mathrm{~h}$. After evacuation of the sample, $\mathrm{CO}_{2}$ was dosed with small increments. Each dose was added only after steady-state establishment. The total number of accessible sites was determined by taking the amount of $\mathrm{CO}_{2}$ chemisorbed at zero pressure obtained by extrapolation of the linear part of the uptake isotherm. $\mathrm{N}_{2}$ physisorption measurements were performed using a Micromeritics Tristar 3000 analyzer after drying the samples at $393 \mathrm{~K}$ for at least $20 \mathrm{~h} . \mathrm{H}_{2}$ chemisorption data on Pd samples were recorded using a Micromeritics ASAP 2010C apparatus. Prior to the chemisorption measurements at $343 \mathrm{~K}$, samples were dried in vacuum at $393 \mathrm{~K}$ for $16 \mathrm{~h}$, reduced in $\mathrm{H}_{2}$ flow at $423 \mathrm{~K}$ for $2 \mathrm{~h}\left(5 \mathrm{~K} \mathrm{~min}^{-1}\right)$ and degassed for $2 \mathrm{~h}$ at the reduction temperature. The $\mathrm{H} / \mathrm{M}$ ratios are based on the amount of hydrogen adsorbed by extrapolating the linear part of the isotherm to zero pressure. TEM images were obtained with a Fei Technai 20 FEG TEM operating at $200 \mathrm{kV}$. Samples were, after ultrasonic treatment, dispersed on a holey carbon film supported on a copper grid. ICP analyses were performed using a Thermo Jarrel Ash Atom Scan 16 apparatus.

\subsection{Catalytic tests}

Condensation and dehydration experiments were performed under $\mathrm{N}_{2}$ atmosphere with $0.5 \mathrm{~g}$ of activated HT catalyst and $1.8 \mathrm{~mol}$ acetone. Hydrogenation experiments and the singlestage synthesis of MIBK were performed in a semi-batch slurry reactor operating at a constant pressure of $1.2 \mathrm{bar}_{2}$ at $313 \mathrm{~K}$ $[25,35]$. The set-up consisted of a thermostated stirred doublewalled glass reactor, equipped with baffles and a gas-tight mechanical stirrer. Typically, for the MIBK synthesis, $0.5 \mathrm{~g} \mathrm{Pd} /$ $\mathrm{HT}_{\text {re }}$ or a physical mixture of $0.5 \mathrm{~g} \mathrm{HT}_{\text {re }}$ with $0.14 \mathrm{~g}$ of Pd/CNF was added to a solution containing $1.8 \mathrm{~mol}$ acetone and $6 \mathrm{~g}$ isooctane as internal standard, after which the reactor was pressurized to $1.2 \mathrm{bar} \mathrm{H}_{2}$. For a typical hydrogenation experiment, $0.05 \mathrm{~g}$ of crushed hydrogenation catalyst was added to a solution containing $120 \mathrm{ml}$ ethanol and $6 \mathrm{~g}$ isooctane at $313 \mathrm{~K}$, after which the reactor was pressurized to 1.2 bar $\mathrm{H}_{2}$. The reaction was started by injection of $0.01 \mathrm{~mol}$ mesityl oxide (Acros, 99\%, $\alpha$ - and $\beta$-isomer ratio 1:13, purified by distillation) or cyclohexene (Acros). Aliquots of $1 \mathrm{ml}$ were taken from the reaction mixture during reaction and analyzed using a Chrompack CP 9001 GC provided with a Chrompack CP 9050 autosampler.

\section{Results and discussion}

\subsection{Catalyst characterization}

The XRD pattern of the as-synthesized $\mathrm{HT}\left(\mathrm{HT}_{\mathrm{as}}\right)$ shows the characteristic diffraction lines typical for an HT compound (Fig. 1). After heat treatment of $\mathrm{HT}_{\text {as }}$ at $773 \mathrm{~K}$ the layered compound was destroyed and a mixed oxide $(\mathrm{Mg}(\mathrm{Al}) \mathrm{O})$ was formed. The original layered structure could be restored by

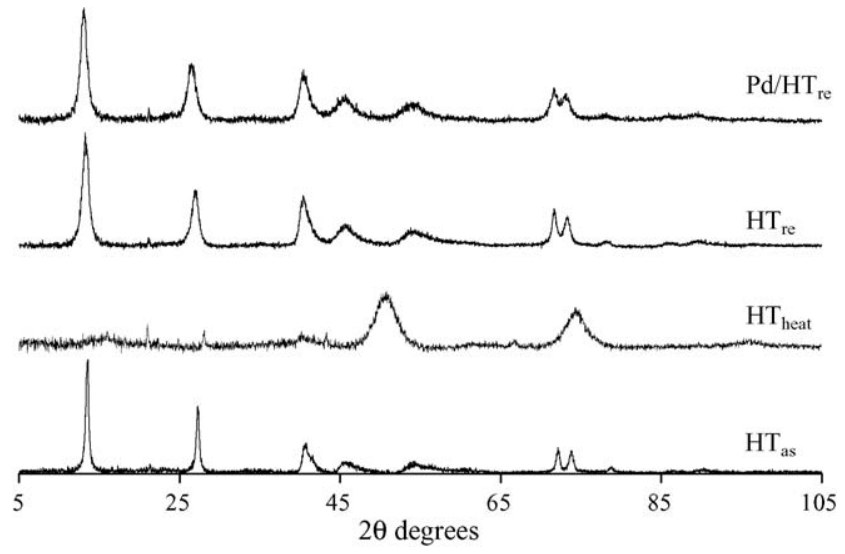

Fig. 1. X-ray diffraction patterns of $\mathrm{HT}_{\mathrm{as}}, \mathrm{HT}_{\text {heat }}, \mathrm{HT}_{\mathrm{re}}$ and $1 \mathrm{wt} \% \mathrm{Pd} / \mathrm{HT}_{\text {re }}$.

rehydration of the mixed oxide, although line broadening in the pattern of $\mathrm{HT}_{\mathrm{re}}$ is apparent compared with the pattern of $\mathrm{HT}_{\mathrm{as}}$. Palladium was deposited on the mixed oxide and, after a second heat treatment at $773 \mathrm{~K}$ and reduction at $473 \mathrm{~K}$, rehydrated to form palladium supported on activated hydrotalcites $\left(\mathrm{Pd} / \mathrm{HT}_{\text {re }}\right)$ with loadings in the range $0-1 \mathrm{wt} \%$. The line broadening is even more pronounced with $\mathrm{Pd} / \mathrm{HT}_{\mathrm{re}}$, caused by the additional synthesis steps needed for deposition of Pd and/or due to the rehydration procedure in the vapor phase instead of the liquidphase. No diffraction lines from Pd are apparent in the XRD pattern due to the low loading and small Pd particles.

The results from $\mathrm{N}_{2}$ physisorption of $\mathrm{HT}_{\mathrm{as}}, \mathrm{HT}_{\text {heat }}, \mathrm{HT}_{\text {re }}$ and $\mathrm{Pd} / \mathrm{HT}_{\mathrm{re}}(1 \mathrm{wt} \%)$ are given in Table 1. After heat treatment of $\mathrm{HT}_{\mathrm{as}}$ the surface area as well as the pore volume increased significantly. Only with $\mathrm{HT}_{\text {heat }}$ micropores were observed, caused by the evolution of water and $\mathrm{CO}_{2}$ during heat treatment of $\mathrm{HT}_{\mathrm{as}}[25,32,36,37]$. After rehydration of the mixed oxide $\left(\mathrm{HT}_{\mathrm{re}}\right)$ a BET surface area similar to that of $\mathrm{HT}_{\mathrm{as}}$ was found, whereas $\mathrm{Pd} / \mathrm{HT}_{\text {re }}$ exhibited a relatively low surface area. The results from $\mathrm{N}_{2}$ physisorption of $\mathrm{Pd} / \mathrm{CNF}$ and $\mathrm{Pd} / \mathrm{SiO}_{2}$ are given in Table 1. No micropores were present in $\mathrm{Pd} / \mathrm{CNF}$, whereas micropores were observed in $\mathrm{Pd} / \mathrm{SiO}_{2}$.

Volumetric $\mathrm{CO}_{2}$ adsorption measurements were performed to obtain information on the number of active base sites in the $\mathrm{HT}$ samples (Table 1). The amount of $\mathrm{CO}_{2}$ adsorbed on all $\mathrm{Pd} /$ $\mathrm{HT}_{\mathrm{re}}$ samples was found in the range $0.05-0.08 \mathrm{mmol} \mathrm{g}_{\mathrm{cat}}{ }^{-1}$, a factor of 2-3 lower than was found for $\mathrm{HT}_{\mathrm{re}}\left(0.17 \mathrm{mmol} \mathrm{g}_{\mathrm{cat}}{ }^{-1}\right)$

Table 1

Results from $\mathrm{N}_{2}$ physisorption and $\mathrm{CO}_{2}$ adsorption measurements

\begin{tabular}{lclll}
\hline & $S^{\mathrm{a}}\left(\mathrm{m}^{2} \mathrm{~g}^{-1}\right)$ & $\begin{array}{l}V_{\text {meso }} \\
\left(\mathrm{cm}^{3} \mathrm{~g}^{-1}\right)\end{array}$ & $\begin{array}{l}V_{\text {micro }} \\
\left(\mathrm{cm}^{3} \mathrm{~g}^{-1}\right)\end{array}$ & $\begin{array}{l}\mathrm{CO}_{2} \text { adsorption } \\
\left(\mathrm{mmol} \mathrm{g}_{\text {cat }}{ }^{-1}\right)\end{array}$ \\
\hline $\mathrm{HT}_{\text {as }}$ & 62 & 0.56 & 0.00 & n.d. \\
$\mathrm{HT}_{\text {heat }}$ & 212 & 0.77 & 0.01 & n.d. \\
$\mathrm{HT}_{\text {re }}$ & 67 & 0.38 & 0.00 & 0.174 \\
$\mathrm{Pd} / \mathrm{HT}_{\text {re }}$ & 27 & 0.24 & 0.00 & 0.076 \\
$\quad(1 \mathrm{wt} \%)$ & & & & \\
$\mathrm{Pd} / \mathrm{CNF}$ & 138 & 0.40 & 0.00 & n.d. \\
$\mathrm{Pd} / \mathrm{SiO}_{2}$ & 278 & 0.91 & 0.02 & n.d. \\
\hline
\end{tabular}

${ }^{\text {a }}$ Calculated with the BET method or from the $t$-plot when micropores were present. 
and values reported earlier for similar materials [32,33,37-40]. This low amount of accessible basic sites is best explained by further agglomeration of the HT platelets as could already be observed with activated HTs $[33,37,38,41,42]$, induced by the additional heat treatment and rehydration procedure. This is supported by considering the density of sites, which is in both types of samples $2.6-2.8 \mathrm{mmol} \mathrm{m}^{-2}$. The regular stacks of hexagonal platelets present in the as-synthesized HT have been transformed into agglomerates of irregular stacks (Fig. 2A).

TEM analysis of $\mathrm{Pd} / \mathrm{HT}_{\text {re }}$ at higher magnification and in STEM High-Angle Annular Dark-Field mode (HAADF) shows that $\mathrm{Pd}$ is distributed as small particles $(1-3 \mathrm{~nm})$ in the HT agglomerates, imaged as small black dots in Fig. $2 \mathrm{~B}$ and as small white dots in Fig. 2C, respectively. The Pd particle size

(A)

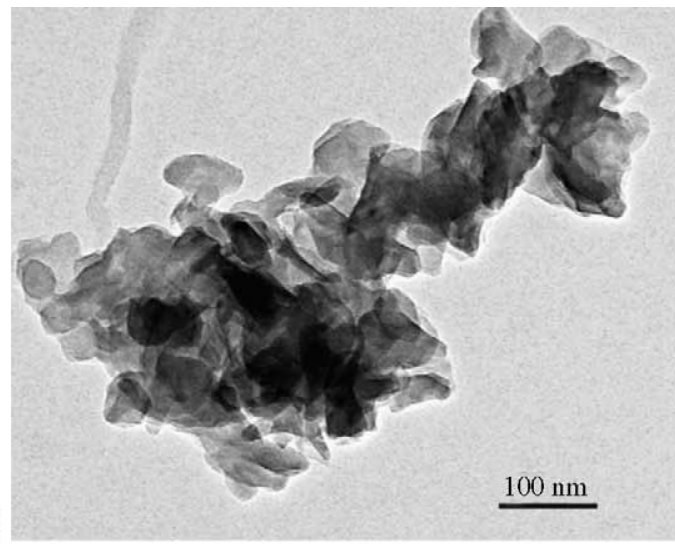

(B)

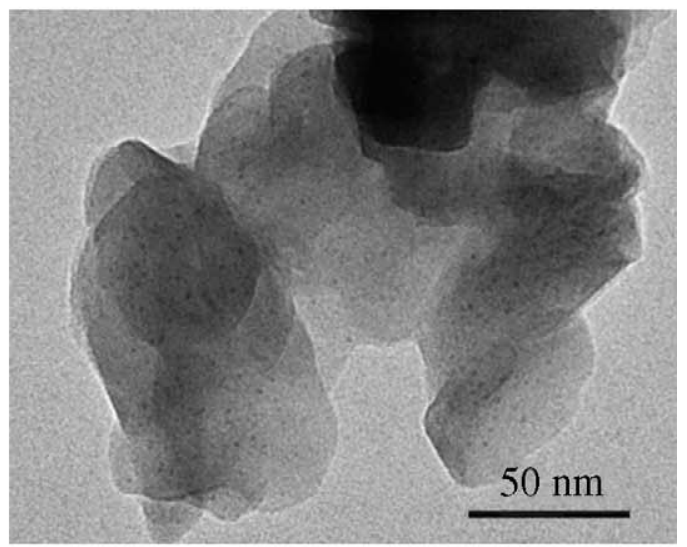

(C)

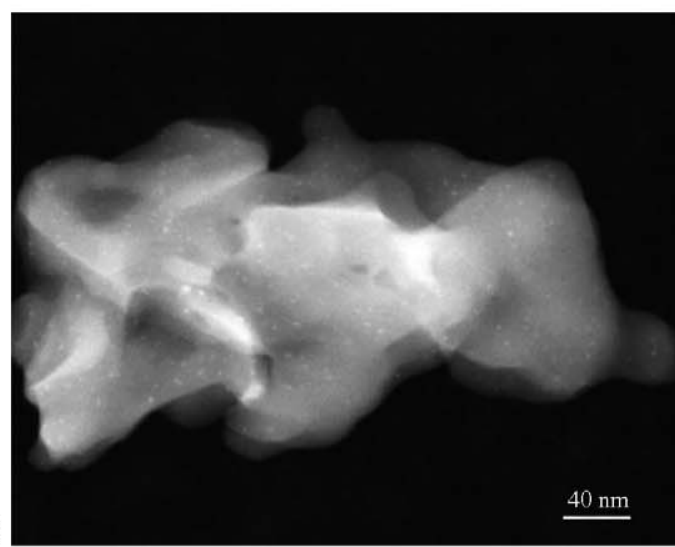

Fig. 2. TEM images of $1 \mathrm{wt} \% \mathrm{Pd} / \mathrm{HT}_{\mathrm{re}}$ : (A and B) bright field, (C) STEM HAADF
Table 2

Characterization results for the various hydrogenation catalysts

\begin{tabular}{lllll}
\hline & $\begin{array}{l}\text { Pd-loading } \\
(\mathrm{ICP}, \mathrm{wt} \%)\end{array}$ & $\begin{array}{l}\text { Pd particle size } \\
(\mathrm{TEM}, \mathrm{nm})\end{array}$ & \multicolumn{2}{l}{$\mathrm{H}_{2}$ chemisorption } \\
\cline { 4 - 5 } & & & $\mathrm{H} / \mathrm{M}$ (at/at) & $d(\mathrm{~nm})$ \\
\hline $\mathrm{Pd} / \mathrm{HT}_{\mathrm{re}}$ & 1 & $1-3$ & 0.71 & 1.6 \\
$\mathrm{Pd} / \mathrm{CNF}$ & 0.9 & $1-4$ & 0.43 & 2.6 \\
$\mathrm{Pd} / \mathrm{SiO}_{2}$ & 2.8 & $1-3$ & 0.75 & 1.5 \\
\hline
\end{tabular}

for all $\mathrm{Pd} / \mathrm{HT}_{\text {re }}$ samples as determined with $\mathrm{H}_{2}$ chemisorption was typically $1.6 \mathrm{~nm}$ (Table 2). TEM analyses on Pd/CNF and $\mathrm{Pd} / \mathrm{SiO}_{2}$ revealed small particles in the range of $1-4 \mathrm{~nm}$ as well, in line with results from $\mathrm{H}_{2}$ chemisorption (Table 2).

\subsection{Condensation and dehydration over activated HTs}

The formation of $\mathrm{MO}$ from acetone over $\mathrm{HT}_{\mathrm{re}}$ was investigated at various temperatures. Fig. 3 displays the initial rate in the dehydration reaction over $\mathrm{HT}_{\text {re }}$ as a function of the reaction temperature. In these experiments the condensation of acetone to DAA was found to be much faster than the dehydration reaction by almost two orders of magnitude. As expected, the dehydration rate enhances considerably upon increasing the reaction temperature, but this improvement is limited due to the relatively low boiling point of acetone at ambient pressure. A perfect fit of the experimental data was obtained with an activation energy of $73.5 \mathrm{~kJ} \mathrm{~mol}^{-1}$ (Fig. 3), which is similar to values reported in literature $[3,43,44]$.

Other investigations reported in literature showed that the actual active basic sites in activated HTs are situated at the edges of the platelets and that the number of these sites can be varied by changing the lateral platelet size $[38,40,41,45,46]$. A linear correlation between the number of active sites and the activity in the condensation of acetone at $273 \mathrm{~K}$ was found $[38,40,46]$. We investigated whether a similar structure-activity relationship could be derived for the dehydration reaction as the dehydration reaction is also catalyzed by basic sites [1]. To this end we have prepared HTs with increasing platelet size by increasing the synthesis temperature, 333, 373, 423 and $473 \mathrm{~K}$ $[38,47]$. TEM- and SEM-analyses of these samples showed that HT prepared at $473 \mathrm{~K}$ consisted of large platelets of about

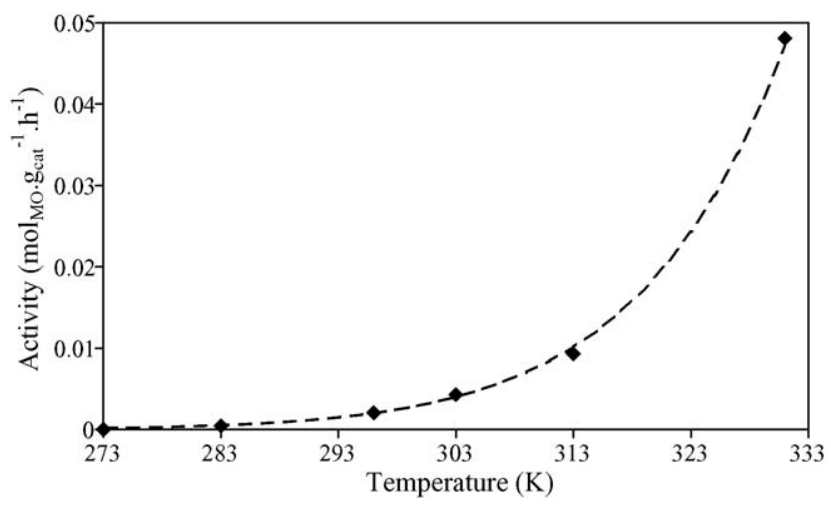

Fig. 3. Initial activity in the dehydration of DAA to MO over $\mathrm{HT}_{\mathrm{re}}$ as a function of the temperature, $(\diamond)$ experimental data and (dashed line) fitted curve (fitted with an activation energy of $73.5 \mathrm{~kJ} \mathrm{~mol}^{-1}$ ). 


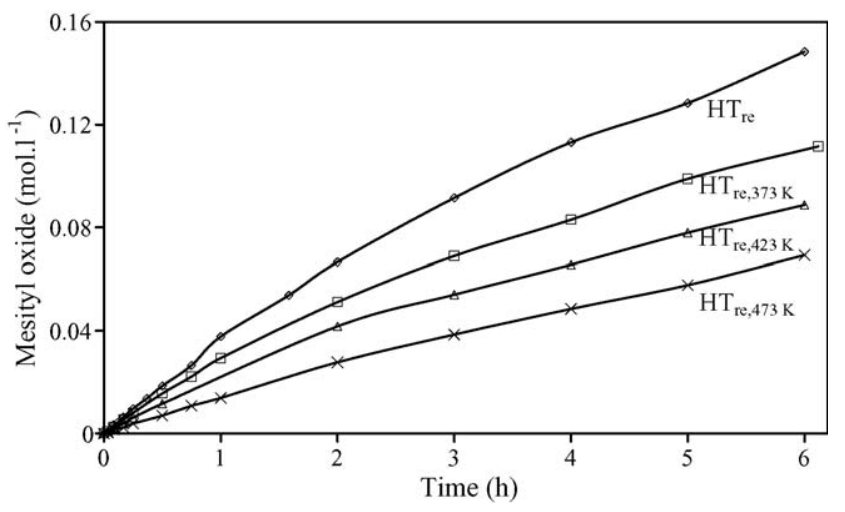

Fig. 4. Formation of mesityl oxide at $313 \mathrm{~K}$ over $\mathrm{HT}_{\mathrm{re}}$ samples with varying platelet size, prepared at $333 \mathrm{~K}\left(\mathrm{HT}_{\mathrm{re}}\right)$, at $373 \mathrm{~K}\left(\mathrm{HT}_{\mathrm{re}, 373 \mathrm{~K}}\right)$, at $423 \mathrm{~K}$ $\left(\mathrm{HT}_{\mathrm{re}, 423 \mathrm{~K}}\right)$ and at $473 \mathrm{~K}\left(\mathrm{HT}_{\mathrm{re}, 473 \mathrm{~K}}\right) .1 .8 \mathrm{~mol}$ acetone and $0.5 \mathrm{~g}$ catalyst were initially present.

$400-500 \mathrm{~nm}$, whereas the smallest platelets $(\sim 60-90 \mathrm{~nm})$ were found for HT prepared at $333 \mathrm{~K}$ (data not shown). These materials were, after activation, investigated in the condensation and dehydration to $\mathrm{MO}$ at $313 \mathrm{~K}$ (Fig. 4). In all experiments equilibrium $\left(\sim 0.45 \mathrm{~mol}_{\mathrm{DAA}} \mathrm{l}^{-1}\right)$ in the condensation of acetone was established within $15 \mathrm{~min}$. The initial activity in the MO formation increases with decreasing platelet size (Fig. 4), similar to results obtained in the condensation of acetone. The number of active sites in these materials was determined by volumetric $\mathrm{CO}_{2}$ adsorption measurements at low pressures. In Fig. 5 the initial activity in the dehydration reaction is given as a function of the $\mathrm{CO}_{2}$ uptake. As expected the number of active sites increased upon decreasing the platelet size. A similar correlation was obtained for the dehydration of DAA to MO as was reported earlier for the self-condensation of acetone, indicating that the dehydration reaction also proceeds via the basic sites situated at the edges of the platelets, although an involvement of structural $\mathrm{OH}$ groups in the catalytic mechanism is not excluded $[48,49]$. No obvious correlation could be derived when using the surface area of the various HT samples as derived from $\mathrm{N}_{2}$ physisorption.

Water is one of the products of the dehydration reaction; therefore, an exploratory investigation on the influence of water on the catalytic properties was performed. The influence of water

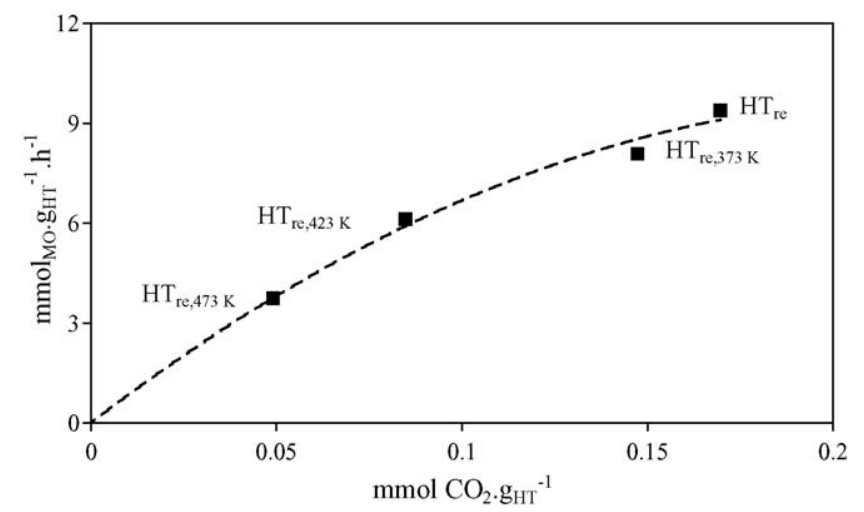

Fig. 5. Initial activity in the dehydration reaction vs. the number of active sites as determined by volumetric $\mathrm{CO}_{2}$ adsorption measurements.
Table 3

Rates in the self-condensation of acetone to DAA and the dehydration to MO at $313 \mathrm{~K}$ over $\mathrm{HT}_{\mathrm{re}}$ with increasing initial water concentration

\begin{tabular}{lll}
\hline$\left[\mathrm{H}_{2} \mathrm{O}\right]_{\mathrm{o}}\left(\mathrm{mol} \mathrm{l}^{-1}\right)$ & \multicolumn{2}{l}{ Initial activity $^{\mathrm{a}}\left(\mathrm{mol}_{\text {product }} \mathrm{g}^{-1} \mathrm{~h}^{-1}\right)$} \\
\cline { 2 - 3 } & Condensation & Dehydration \\
\hline 0 & 1.1 & $9.4 \times 10^{-3}$ \\
0.25 & 0.39 & $3.1 \times 10^{-3}$ \\
\hline
\end{tabular}

${ }^{a}$ Initial activity in the condensation reaction over the first $2 \mathrm{~min}$, in the dehydration reaction over the first $15 \mathrm{~min}$.

added prior to reaction was investigated in the self-condensation of acetone to DAA and the consecutive dehydration of DAA to $\mathrm{MO}$ at $313 \mathrm{~K}$ (Table 3). The influence of water on the activity of $\mathrm{HT}_{\text {re }}$ was also investigated in the self-condensation at $273 \mathrm{~K}$, at a temperature at which no dehydration of DAA to MO occurs, by adding water prior to reaction as well as during the experiment. Fig. 6 shows the relative initial activity as a function of the water content initially present. The initial rate in the condensation of acetone drops considerably by adding small amounts of water. When performing the reaction at $313 \mathrm{~K}$ the rate of the dehydration reaction decreased by a factor of 3 when increasing the initial water concentration to $0.25 \mathrm{~mol}^{-1}$ (Table 3 ). The rate of the condensation reaction was much higher than that of the dehydration reaction, by two orders of magnitude. When adding water to the reaction mixture, surprisingly, the rate of the condensation reaction dropped by a factor of 2.8 . When one considers the catalytic mechanism of the base-catalyzed condensation of acetone to DAA and its consecutive dehydration to $\mathrm{MO}$, the Brønsted-base sites abstract an $\alpha$ hydrogen yielding an enolate ion as reaction intermediate in both type of reactions [1]. Accordingly, an increasing water concentration shifts the condensation reaction to acetone and the dehydration to DAA, respectively. Assuming that the rate of $\mathrm{MO}$ production is firstorder in the concentration of DAA, these results demonstrate that $\mathrm{H}_{2} \mathrm{O}$ does suppress the self-condensation of acetone but does not considerably affect the dehydration of DAA to MO for reasons unknown. These results as well as those reported by other authors [50-52] show that the water concentration in the reaction mixture is a crucial parameter influencing the catalytic performance of activated hydrotalcites.

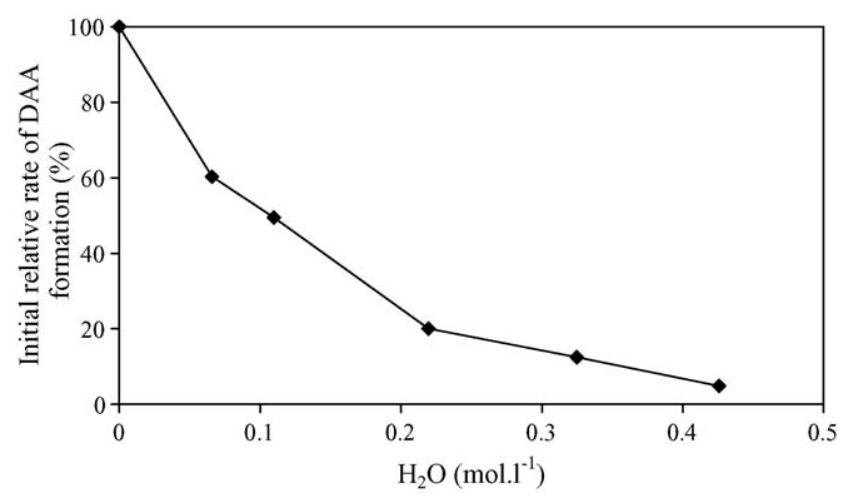

Fig. 6. Decrease in initial activity in the self-condensation of acetone as a function of the water content added to the reaction mixture at $273 \mathrm{~K}$ over $\mathrm{HT}_{\mathrm{re}}$. 

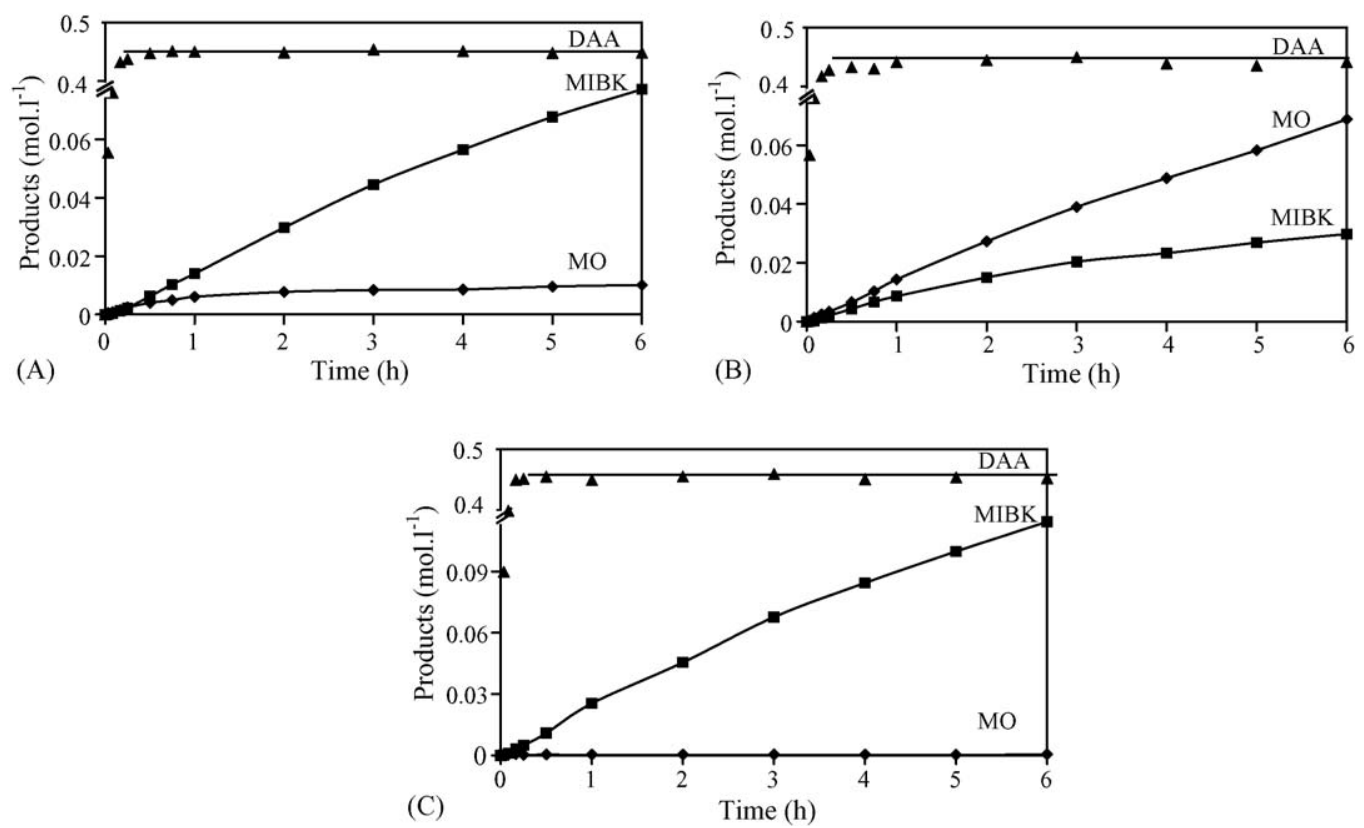

Fig. 7. Formation of DAA, MO and MIBK in the single-stage synthesis of MIBK from acetone and $\mathrm{H}_{2}(1.2 \mathrm{bar})$ at $313 \mathrm{~K}$ over $0.5 \mathrm{~g}$ catalyst. (A) $1 \mathrm{wt} \% \mathrm{Pd} / \mathrm{HT}_{\mathrm{re}}$. (B) $0.25 \mathrm{wt} \% \mathrm{Pd} / \mathrm{HT}_{\mathrm{re}}$. (C) Physical mixture of $\mathrm{HT}_{\mathrm{re}}$ and $\mathrm{Pd} / \mathrm{CNF}(0.5 \mathrm{~g} \mathrm{HT}$ re and $0.14 \mathrm{~g} \mathrm{Pd} / \mathrm{CNF})$.

\subsection{Single-stage synthesis of MIBK}

The $\mathrm{Pd} / \mathrm{HT}_{\mathrm{re}}$ samples and physical mixtures of $\mathrm{HT}_{\mathrm{re}}$ and $\mathrm{Pd} /$ $\mathrm{CNF}$ were investigated in the single-stage synthesis of MIBK at

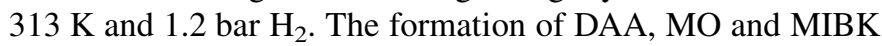
over 0.25 and $1 \mathrm{wt} \% \mathrm{Pd} / \mathrm{HT}_{\mathrm{re}}$ as well as the physical mixture of $\mathrm{HT}_{\text {re }}$ with $\mathrm{Pd} / \mathrm{CNF}(0.25 \mathrm{wt} \%$ Pd with respect to the amount of $\mathrm{HT}_{\mathrm{re}}$ ) is shown in Fig. 7 and Table 4. The acetone condensation was fast and equilibrium was attained already within $15 \mathrm{~min}$. With $1 \mathrm{wt} \% \mathrm{Pd} / \mathrm{HT}_{\text {re }}$ the $\mathrm{MO}$ concentration remained low due to rapid hydrogenation to MIBK (Fig. 7A). However, with $0.25 \mathrm{wt} \% \mathrm{Pd} / \mathrm{HT}_{\mathrm{re}}$ the $\mathrm{MO}$ concentration increased continuously during several hours of reaction, whereas the MIBK formation was much slower and even slowed down with time (Fig. 7B). In the latter case the hydrogenation activity gradually decreased during the experiment likely due to catalyst

Table 4

MIBK production rate and reaction mixture composition in the single-stage

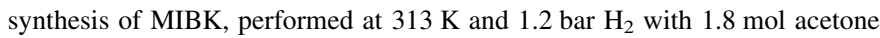
initially present

\begin{tabular}{|c|c|c|c|c|c|}
\hline & \multirow{2}{*}{$\begin{array}{l}\text { MIBK production } \\
\text { rate }^{\mathrm{a}}\left(\mathrm{mmol} \mathrm{g}_{\mathrm{cat}}^{-1} \mathrm{~h}^{-1}\right)\end{array}$} & \multicolumn{4}{|c|}{ Products $(\mathrm{mol} \%)^{\mathrm{b}}$} \\
\hline & & DAA & MO & MIBK & Other $^{\mathrm{c}}$ \\
\hline $\mathrm{HT}_{\mathrm{re}}$ & 0 & 81.9 & 17.0 & 0 & 1.1 \\
\hline $\mathrm{Pd} / \mathrm{HT}_{\mathrm{re}}(0.25 \mathrm{wt} \%)$ & 2.0 & 80.7 & 12.6 & 5.5 & 1.2 \\
\hline $\mathrm{Pd} / \mathrm{HT}_{\mathrm{re}}(0.5 \mathrm{wt} \%)$ & 2.3 & 82.1 & 10.4 & 6.5 & 1.0 \\
\hline $\mathrm{Pd} / \mathrm{HT}_{\mathrm{re}}(0.75 \mathrm{wt} \%)$ & 2.6 & 82.3 & 5.9 & 9.9 & 1.9 \\
\hline $\mathrm{Pd} / \mathrm{HT}_{\mathrm{re}}(1 \mathrm{wt} \%)$ & 3.9 & 81.6 & 1.8 & 13.7 & 2.9 \\
\hline $\mathrm{Pd} / \mathrm{CNF}$ and $\mathrm{HT}_{\mathrm{re}}{ }^{\mathrm{d}}$ & 5.7 & 78.2 & 0.2 & 19.9 & 1.7 \\
\hline
\end{tabular}

${ }^{\mathrm{a}}$ Calculated for the first hour.

${ }^{\mathrm{b}}$ Determined after $6 \mathrm{~h}$.

${ }^{c}$ Main side products are isopropanol, isophorone and triacetone alcohol.

${ }^{\mathrm{d}}$ Physical mixture of $0.50 \mathrm{~g} \mathrm{HT}_{\text {re }}$ and $0.14 \mathrm{~g} \mathrm{Pd} / \mathrm{CNF}$. deactivation [25]. Fig. 8 shows the results from the catalytic experiments obtained with the whole series of $\mathrm{Pd} / \mathrm{HT}_{\mathrm{re}}$ samples with Pd-loadings ranging from 0 to $1 \mathrm{wt} \%$. A clear dependency of the MIBK formation on the Pd-loading was found. At Pdloadings up to $0.75 \mathrm{wt} \%$ the catalyst could not keep the MO concentration low (Table 4). At Pd-loadings of $1 \mathrm{wt} \%$ the rate of hydrogenation was high enough to keep the MO concentration at such a low level that deactivation was suppressed. The dehydration activity (calculated from the amounts of $\mathrm{MO}$ and MIBK formed) is given in Fig. 8 as well. The dehydration activity of $\mathrm{HT}_{\mathrm{re}}$ was significantly higher than that of $\mathrm{Pd} / \mathrm{HT}_{\mathrm{re}}$, in line with the measured number of active sites (Table 1).

Results from experiments using a physical mixture of $\mathrm{Pd} /$ $\mathrm{CNF}$ and $\mathrm{HT}_{\mathrm{re}}(0.25 \mathrm{wt} \% \mathrm{Pd}$ with respect to the amount of $\mathrm{HT}_{\mathrm{re}}$ ) are given in Fig. $7 \mathrm{C}$ and Table 4. With the physical mixture the MO concentration could be kept very low at a

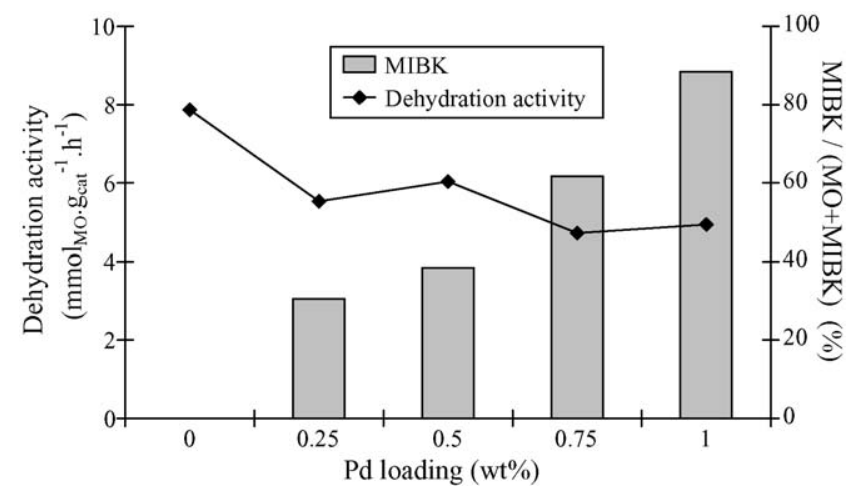

Fig. 8. Dehydration activity (first hour) and the relative conversion of MO to MIBK as a function of the Pd-loading in the single-stage synthesis of MIBK at $313 \mathrm{~K}$ over $\mathrm{Pd} / \mathrm{HT}_{\mathrm{re}}$ samples. 
Table 5

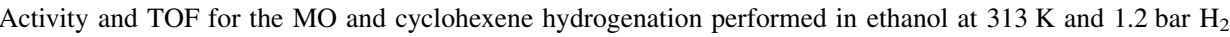

\begin{tabular}{|c|c|c|c|c|}
\hline & \multicolumn{2}{|l|}{ MO hydrogenation } & \multicolumn{2}{|l|}{ Cyclohexene hydrogenation } \\
\hline & Initial activity $\times 10^{3}\left(\mathrm{~mol} \mathrm{~g}_{\mathrm{Pd}}^{-1} \mathrm{~s}^{-1}\right)$ & $\operatorname{TOF}^{\mathrm{a}}\left(\mathrm{s}^{-1}\right)$ & Initial activity $\times 10^{3}\left(\mathrm{~mol} \mathrm{~g}_{\mathrm{Pd}}^{-1} \mathrm{~s}^{-1}\right)$ & $\operatorname{TOF}^{\mathrm{a}}\left(\mathrm{s}^{-1}\right)$ \\
\hline $\mathrm{Pd} / \mathrm{HT}_{\mathrm{re}}(1 \mathrm{wt} \%)$ & 0.94 & 0.14 & 1.5 & 0.22 \\
\hline $\mathrm{Pd} / \mathrm{CNF}$ & 24 & 5.3 & 11 & 2.8 \\
\hline $\mathrm{Pd} / \mathrm{SiO}_{2}$ & 9.1 & 1.5 & 11 & 1.6 \\
\hline
\end{tabular}

${ }^{a}$ TOF is given for the first $2 \mathrm{~min}$ in mol $_{\text {reactant }}$ hydrogenated per mole metal surface atoms in the catalyst per second.

relative loading of $0.25 \mathrm{wt} \% \mathrm{Pd}$ (at a much lower Pd-loading than with the $\mathrm{Pd} / \mathrm{HT}_{\text {re }}$ samples). Moreover, with this catalyst system a rather constant MIBK formation was found over several hours of reaction.

The difference in catalytic performance between the $\mathrm{Pd} / \mathrm{HT}_{\mathrm{re}}$ samples and the physical mixtures can be ascribed to either a support-effect or to partly loss of the hydrogenation sites in the $\mathrm{Pd} / \mathrm{HT}_{\text {re }}$ samples brought about by agglomeration of the HT platelets due to which part of the hydrogenation sites have become inaccessible for the reactants. Results from $\mathrm{N}_{2}$ physisorption, XRD and especially TEM indicated the extensive formation of agglomerates with $\mathrm{Pd} / \mathrm{HT}_{\mathrm{re}}$. The low amount of $\mathrm{CO}_{2}$ adsorbed on these materials as well as the low hydrogenation activity further indicate a loss of basic sites as well as hydrogenation sites. Due to the favorable physico-chemical properties of the carbon nanofibers support, such effects can be excluded for $\mathrm{Pd} / \mathrm{CNF}$. It must be mentioned that a relatively high $\mathrm{H} / \mathrm{Pd}$ was obtained from $\mathrm{H}_{2}$ chemisorption for the $\mathrm{Pd} / \mathrm{HT}_{\mathrm{re}}$ samples (similar to that of $\mathrm{Pd} / \mathrm{SiO}_{2}$ ), which indicates that accessibility of $\mathrm{Pd}$ for $\mathrm{H}_{2}$ does not pose a problem. To elucidate on the supposition of partly loss of Pd particles in the HT agglomerates direct MO hydrogenation experiments over $\mathrm{Pd} /$ $\mathrm{HT}_{\text {re }}$ have been performed and the results are compared to those obtained with $\mathrm{Pd} / \mathrm{CNF}$ and $\mathrm{Pd} / \mathrm{SiO}_{2}$. Cyclohexene hydrogenation experiments were investigated as well, because this reaction is expected not to be influenced by the basic sites present in $\mathrm{Pd} / \mathrm{HT}_{\mathrm{re}}$ and water present in the reaction mixture.

\subsection{Hydrogenation of MO and cyclohexene}

Earlier we reported that the nature of the support might affect the activity in the hydrogenation of $\mathrm{MO}$ and that severe deactivation of the catalyst occurred especially when applying relatively high $\mathrm{MO}$ concentrations $\left(\sim 0.3 \mathrm{~mol} \mathrm{l}^{-1}\right)$ at low $\mathrm{H}_{2}$ pressure (1 bar) [25]. Therefore, the hydrogenation of cyclohexene was performed as well. In Fig. 9 the hydrogenation of MO and of cyclohexene over $(1 \mathrm{wt} \%) \mathrm{Pd} / \mathrm{HT}_{\mathrm{re}}$ and $(0.9 \mathrm{wt} \%) \mathrm{Pd} / \mathrm{CNF}$ at $313 \mathrm{~K}$ and 1.2 bar $\mathrm{H}_{2}$ are depicted. The initial rate in the hydrogenation of cyclohexene was somewhat lower than the rate in the hydrogenation of MO over all catalysts. Clear differences in catalytic performance between $\mathrm{Pd} / \mathrm{CNF}$ and $\mathrm{Pd} / \mathrm{HT}_{\mathrm{re}}$ were observed in both reactions. In Table 5 the initial activity as well as the turn-over frequency (TOF, based on hydrogen chemisorption data) are given for the hydrogenation catalysts. The initial activity and TOF in the MO hydrogenation of $\mathrm{Pd} / \mathrm{CNF}$ and $\mathrm{Pd} /$ $\mathrm{SiO}_{2}$ differ somewhat, while these differences are less pronounced in the cyclohexene hydrogenation. However, both

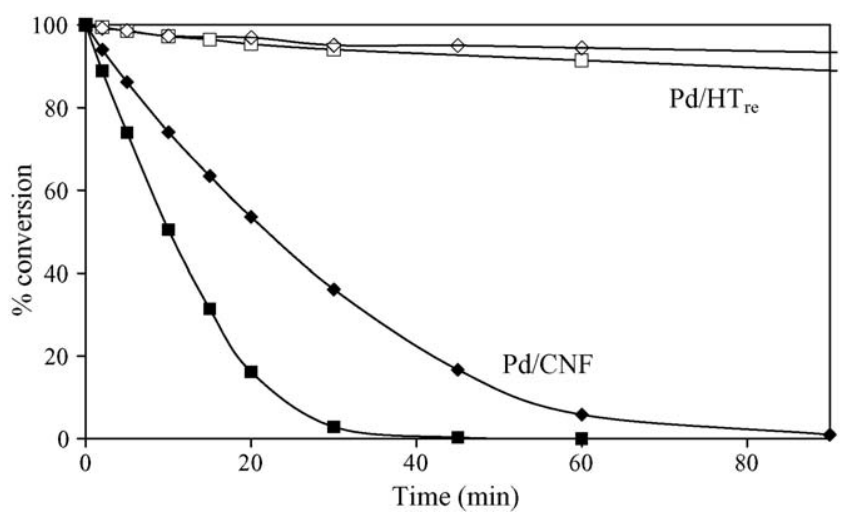

Fig. 9. Hydrogenation of $\mathrm{MO}\left(0.08 \mathrm{~mol} \mathrm{l}^{-1}\right)$ and hydrogenation of cyclohexene $\left(0.08 \mathrm{~mol} \mathrm{l^{-1 }}\right)$ over $(1 \mathrm{wt} \%) \mathrm{Pd}_{\mathrm{H}} \mathrm{HT}_{\mathrm{re}}(\square$ and $\diamond$, respectively) and $\mathrm{Pd} / \mathrm{CNF}($ and $\diamond$, respectively) performed in ethanol at 1.2 bar $\mathrm{H}_{2}$ and $313 \mathrm{~K}$.

catalysts exhibited much higher activity than $\mathrm{Pd} / \mathrm{HT}_{\mathrm{re}}$. The difference in TOF was found to be as large as 30 times that for the MO hydrogenation and 11 times that for the cyclohexene hydrogenation. Such large differences have not been reported earlier for hydrogenation of cyclohexene using $\mathrm{Rh}$ and $\mathrm{Pd}$ catalysts [35,53]. Jackson et al. [53] studied the hydrogenation of cyclohexene over $\mathrm{Pd}$ /alumina, $\mathrm{Pd} /$ carbon, $\mathrm{Pd} /$ silica and $\mathrm{Pd} /$ zirconia catalysts and found relatively small variations in the TOF, that is, differences only up to a factor of 2 . Activities obtained for our $\mathrm{Pd} / \mathrm{CNF}$ and $\mathrm{Pd} / \mathrm{SiO}_{2}$ catalysts are quite similar.

Although the lower activity in the hydrogenation of $\mathrm{MO}$ might partly be ascribed to the nature of the support, these results suggest partly entrapment of $\mathrm{Pd}$ particles in the agglomerates of HT, making these less accessible for the organic reactants. Since hydrogen chemisorption on $\mathrm{Pd} / \mathrm{HT}_{\mathrm{re}}$ is similar to $\mathrm{Pd} / \mathrm{SiO}_{2}$ (Table 2), accessibility of $\mathrm{H}_{2}$ does not pose a problem. The use of $\mathrm{HT}_{\mathrm{re}}$ as support for Pd appears to affect the performance of the catalyst negatively and shows that the physical mixture of $\mathrm{HT}_{\mathrm{re}}$ with $\mathrm{Pd} / \mathrm{CNF}$ is superior over $\mathrm{Pd} / \mathrm{HT}_{\mathrm{re}}$ bi-functional catalysts in the liquid-phase synthesis of MIBK under mild conditions.

\section{Conclusions}

Pd supported on activated hydrotalcites and physical mixtures of activated hydrotalcites with $\mathrm{Pd}$ on carbon nanofibers catalysts were studied for the single-stage synthesis of methyl isobutyl ketone from acetone and $\mathrm{H}_{2}$. The rate of the dehydration reaction over activated hydrotalcites was found to be dependent on the number of strongly basic sites, similar to 
the correlation found in the self-condensation of acetone over activated hydrotalcites. Deposition of Pd on activated hydrotalcites resulted in agglomerates of irregular stacks of hydrotalcite platelets that cause inclusion of a large part of the Pd particles. The conversion of MO to MIBK in the singlestage experiments turned out to be dependent on the palladium loading, which was not observed with physical mixtures of activated hydrotalcites and Pd supported on carbon nanofibers. Very low activities and TOFs in the hydrogenation of mesityl oxide and of cyclohexene were obtained with the Pd supported on hydrotalcites catalysts compared to the other hydrogenation catalysts, which we ascribe to entrapment of Pd particles in the hydrotalcite agglomerates making them less accessible for the organic reactants.

\section{Acknowledgements}

The authors are grateful to V. Koot, A.J.M. Mens, J.W. Geus and J.D. Meeldijk for their technical assistance. C. van der Burg and V.S. Gevaerts are acknowledged for their research on $\mathrm{Pd}$ supported on activated hydrotalcites catalysts. The Netherlands Technology Foundation (CW/STW 790.35.733) is acknowledged for financial support.

\section{References}

[1] J. McMurry, Organic Chemistry, Brooks/Cole Publishing Company, Pacific Grove, 1995, p. 896.

[2] G.G. Podrebarac, F.T.T. Ng, G.L. Rempel, Chem. Eng. Sci. 52 (1997) 2991.

[3] Y.K. Kim, J.D. Hatfield, J. Chem. Eng. Data 30 (1985) 149.

[4] E.C. Craven, J. Appl. Chem. 13 (1963) 71.

[5] C.U. Pittman Jr., Y.F. Liang, J. Org. Chem. 45 (1980) 5048.

[6] L. Melo, G. Gianetto, L. Cardozo, A. Llanos, L. García, P. Magnoux, M. Guisnet, F. Alvarez, Catal. Lett. 60 (1999) 217.

[7] D. Bombos, G. Bozga, M. Bombos, A. Stefan, I. Stanciu, Chem. Papers 54 (2000) 171.

[8] P.Y. Chen, S.J. Chu, W.C. Lin, K.C. Wu, C.L. Yang, Stud. Surf. Sci. Catal. 83 (1994) 481.

[9] A.N. Ko, C.H. Hu, J.Y. Chen, Catal. Lett. 54 (1998) 207.

[10] A.N. Ko, C.H. Hu, J.Y. Chen, Appl. Catal. A 184 (1999) 211.

[11] C.A. Hamilton, S.D. Jackson, G.J. Kelly, Appl. Catal. A 263 (2004) 63.

[12] Y.Z. Chen, B.J. Liaw, H.R. Tan, K.L. Shen, Appl. Catal. A 205 (2001) 61.

[13] Y. Higashio, T. Nakayama, Catal. Today 28 (1996) 127.

[14] L.M. Gandia, M. Montes, Appl. Catal. A 101 (1993) L1.

[15] K.H. Lin, A.N. Ko, Appl. Catal. A 147 (1996) L259.

[16] R. Unnikrishan, S. Narayanan, J. Mol. Catal. A Chem. 144 (1999) 173.

[17] A.A. Nikolopoulos, B.W.-L. Jang, R. Subramanian, J.J. Spivey, D.J. Olsen, T.J. Devon, R.D. Culp, ACS Symposium Series 767 (Green Chemical Processes), Charleston, (2000), p. 1994.

[18] N.N. Das, S.C. Srivastava, Bull. Mater. Sci. 25 (2002) 283.
[19] N. Das, D. Tichit, R. Durand, P. Graffin, B. Coq, Catal. Lett. 71 (2001) 181.

[20] Y.Z. Chen, B.J. Liaw, H.R. Tan, K.L. Shen, Appl. Catal. A 169 (1998) 207.

[21] A.A. Nikolopoulos, B.W.L. Jang, J.J. Spivey, Appl. Catal. A 296 (2005) 128.

[22] G.S. Salvapati, K.V. Ramanamurty, M. Janardanarao, J. Mol. Catal. 54 (1989) 9.

[23] S. Lippert, W. Baumann, K. Thomke, J. Mol. Catal. 69 (1991) 199.

[24] K.H. Lawson, B. Nkosi, US Patent 6008416 (1999).

[25] F. Winter, A.J. van Dillen, K.P. de Jong, J. Mol. Catal. A Chem. 219 (2004) 273.

[26] B.M. Choudary, S. Madhi, N.S. Chowdari, M.L. Kantam, B. Screedhar, J. Am. Chem. Soc. 124 (2002) 14127.

[27] S. Albertazzi, G. Busca, E. Finocchio, R. Glöcker, A. Vaccari, J. Catal. 223 (2004) 372.

[28] F. Prinetto, M. Manzoli, G. Ghiotti, M.J. Martinez Ortiz, D. Tichit, B. Coq, J. Catal. 222 (2004) 238.

[29] D. Tichit, B. Coq, S. Cerneaux, R. Durand, Catal. Today 75 (2002) 197.

[30] J.C.A.A. Roelofs, P.H. Berben, Chem. Commun. 8 (2004) 970.

[31] S. Miyata, Clays Clay Miner. 28 (1980) 50.

[32] J.C.A.A. Roelofs, A.J. van Dillen, K.P. de Jong, Catal. Today 60 (2000) 297.

[33] K.K. Rao, M. Gravelle, J. Sanchez-Valente, F. Figueras, J. Catal. 173 (1998) 115.

[34] F. Winter, G.L. Bezemer, C. van der Spek, J.D. Meeldijk, A.J. van Dillen, J.W. Geus, K.P. de Jong, Carbon 43 (2005) 327.

[35] T.G. Ros, D.E. Keller, A.J. van Dillen, J.W. Geus, D.C. Koningsberger, J. Catal. 211 (2002) 85.

[36] W.T. Reichle, S.Y. Kang, D.S. Everhardt, J. Catal. 101 (1986) 352.

[37] F. Winter, X. Xia, B.P.C. Hereijgers, J.H. Bitter, A.J. van Dillen, M. Muhler, K.P. de Jong, J. Phys. Chem. B 110 (2006) 9211.

[38] J.C.A.A. Roelofs, D.J. Lensveld, A.J. van Dillen, K.P. de Jong, J. Catal. 203 (2001) 184.

[39] J. Sanchez Valente, F. Figueras, M. Gravelle, P. Kumbhar, J. Lopez, J.-P. Besse, J. Catal. 189 (2000) 370.

[40] F. Winter, A.J. van Dillen, K.P. de Jong, Chem. Commun. 31 (2005) 3977.

[41] S. Abelló, F. Medina, D. Tichit, J. Pérez-Ramírez, J.C. Groen, J.E. Sueiras, P. Salagre, Y. Cesteros, Chem. Eur. J. 11 (2005) 728.

[42] F. Prinetto, D. Tichit, R. Teissier, B. Coq, Catal. Today 55 (2000) 103.

[43] N.O. Lemcoff, R.E. Cunningham, J. Catal. 23 (1971) 81.

[44] D. Pressman, L. Brewer, H.J. Lucas, J. Am. Chem. Soc. 64 (1942) 1122.

[45] S. Abelló, F. Medina, D. Tichit, J. Pérez-Ramírez, Y. Cesteros, P. Salagre, J.E. Sueiras, Chem. Commun. 11 (2005) 1453.

[46] F. Winter, V. Koot, A.J. van Dillen, J.W. Geus, K.P. de Jong, J. Catal. 236 (2005) 91.

[47] W.T. Reichle, Solid State Ionics 22 (1986) 135.

[48] M.B.J. Roeffaers, B.F. Sels, H. Uji-i, F.C. de Schryver, P.A. Jacobs, D.E. de Vos, J. Hofkens, Nature 439 (2006) 572.

[49] M.-L. Bailly, C. Chizallet, G. Costentin, J.-M. Krafft, H. Lauron-Pernot, M. Che, J. Catal. 235 (2005) 413.

[50] M.J. Climent, A. Corma, S. Iborra, A. Velty, Catal. Lett. 79 (2002) 157.

[51] M.J. Climent, A. Corma, S. Iborra, A. Velty, J. Catal. 221 (2004) 474.

[52] A. Guida, L.M. Hassane, D. Tichit, F. Figueras, P. Geneste, Appl. Catal. A 164 (1997) 251.

[53] S.D. Jackson, G.J. Kelly, S.R. Watson, R. Gulickx, Appl. Catal. A 187 (1999) 161. 